\title{
ANALISIS STRATEGI LANGKAH MUNDUR DAN BERNALAR LOGIS DALAM MENENTUKAN BILANGAN DAN NILAINYA
}

\author{
Landyasari Riffyanti ${ }^{1}$, Rubono Setiawan ${ }^{2)}$ \\ ${ }^{1), 2)}$ Pendidikan Matematika, FKIP, Univ. Sebelas Maret Surakarta \\ Email: diasidias23@gmail.com ${ }^{1)}$, rubono.matematika@staff.uns.ac.id ${ }^{2)}$
}

\begin{abstract}
This study analyzed the mathematical problem solving strategy that combines a backward step and reasoned logically to answer the High School Olympic level problems related to number theory for the district, national, and provincial level which are often issued from year to year. The mentioned problem is more about the application of number theory problem, which is determine a number and the value of the questioned number. The study began by analyzing some Olympic problems. These problems are answered and resolved by a combination of mathematical problem solving strategies, which are backward step and reasoned logically. Implementation of this solving problem should also be adjusted with Polya step which is consists of four stages. Polya step is used to give better structured problem solving. Compared with trial and error method, this analyze can give an effective combination to determine a number and the value of a number.
\end{abstract}

Keywords: backward step strategy, polya step, reasoned logically strategy

\section{PENDAHULUAN}

Pada saat ini, kemampuan siswa dalam belajar sangatlah beragam. Siswa yang mampu belajar dengan baik biasanya tergolong sebagai siswa yang pandai. Kemampuan dari siswa yang pandai biasanya selalu diasah agar menjadi tajam dan berkembang. Kemampuan siswa dapat diukur dari caranya dalam memecahkan suatu masalah. Menurut Budhi dan Kartasasmita (2015), tujuan utama mempelajari matematika adalah dapat menemukan cara menyelesaikan soal atau masalah. Yang dimaksud dengan soal adalah suatu hal yang hasil akhirnya atau cara menyelesaikannya belum diketahui. Kemudian, kemampuan memecahkan masalah adalah sesuatu yang penting. Pentingnya kemampuan memecahkan masalah adalah selain tujuan umum dari pembelajaran matematika, kemampuan pemecahan masalah juga merupakan proses inti dan utama dalam kurikulum matematika dan juga kemampuan dasar dalam pembelajaran matematika.

Masalah dalam matematika dapat digolongkan menjadi dua, yaitu masalah rutin dan non rutin. Masalah rutin adalah masalah yang dapat diselesaikan dan dikerjakan siswa dengan mudah, sedangkan masalah non rutin adalah masalah yang sulit dikerjakan oleh siswa dan perlu keterampilan dalam memecahkannya. Masalah non rutin biasanya dikeluarkan dalam bentuk soal- soal olimpiade baik tingkat kabupaten, provinsi, ataupun nasional. Tingkatan soal- soal olimpiade ini memang sedikit lebih sulit dibandingkan soal- soal yang biasanya diberikan di dalam kelas, sehingga soal 
olimpiade bisa dikategorikan sebagai masalah non rutin.

Olimpiade biasanya diikuti oleh berbagai tingkatan sekolah, mulai dari sekolah dasar, sekolah menengah pertama, sekolah menengah umum, maupun perguruan tinggi. Setiap tingkatan memiliki tingkat kesulitan yang berbeda pula. Matematika adalah salah satu mata pelajaran yang diikuti dalam ajang olimpiade sekolah. Soalsoal yang dikeluarkan pada olimpiade matematika adalah soal- soal yang tidak diajarkan secara mendalam dalam pembelajaran di dalam kelas, sehingga siswa membutuhkan bimbingan ataupun belajar secara khusus sebelum mengikuti olimpiade.

Dalam memecahkan masalah matematika baik itu soal olimpiade maupun soal yang rutin di dalam pembelajaran di kelas, diperlukan strategi- strategi tertentu agar siswa dapat memecahkannya dengan baik. Terdapat berbagai strategi dalam memecahkan masalah matematika, diantaranya adalah bekerja mundur, penemuan pola, melihat dari sudut pandang lain, menyederhanakan masalah serupa, mempertimbangkan kasus ekstrim, membuat gambar/ diagram, menebak dengan cerdas dan mengetesnya, memperhitungkan semua kemungkinan, mengorganisasi data, dan bernalar logis. Dari kesepuluh strategi ini, terdapat ciri- ciri khusus soal seperti apa yang mudah dikerjakan dengan salah satu ataupun kombinasi dari strategi yang ada. Walaupun biasanya satu strategi digunakan untuk menjawab satu pemasalahan, tetapi bisa juga dua ataupun tiga strategi digunakan untuk menyelesaikan suatu permasalahan.

Permasalahan matematika itu sangat banyak sekali jenisnya, seperti geometri, aljabar, statistika, teori bilangan dan masih banyak lagi. Permasalahan- permasalahan tersebut tentunya bisa diselesaikan dengan mudah jika penjawab soal cerdik dalam memilih strategi mana yang akan digunakan. Pada penelitian kali ini, penulis fokus dengan permasalahan matematika bidang teori bilangan dalam menentukan suatu bilangan dan nilainya dengan menggunakan kombinasi dua strategi, yaitu strategi langkah mundur dan bernalar secara logis.

Tujuan dari penelitian ini adalah untuk (1) menganalisis soal- soal teori bilangan dalam olimpiade SMA yang berkaitan dengan menentukan bilangan dan nilainya yang diselesaikan sesuai langkah Polya dengan kombinasi antara strategi langkah mundur dan bernalar secara logis dan (2) untuk menganalisis keefektifan kombinasi strategi langkah mundur dan bernalar secara logis untuk menjawab soal olimpiade SMA yang berkaitan dengan menentukan bilangan dan nilainya.

\section{PEMBAHASAN \\ Masalah Matematika}

Dalam kehidupan kita mengenal masalah sebagai bagian dari kehidupan yang dijalani. Masalah yang dihadapi mempunyai cara penyelesaian yang beragam, hal ini sesuai dengan bagaimana diri kita. Tak hanya dalam kehidupan, masalah juga dikenal dalam pembelajaran, khususnya pelajaran matematika. Biasanya permasalahan yang dimaksud adalah dalam bentuk soal maupun tugas. Soal atau tugas yang dimaksud ini adalah soal yang dapat dimengerti, tetapi menantang untuk diselesaikan.

Lancher (dalam Hartono, 2014: 2) mendeskripsikan masalah matematika sebagai soal matematika yang strategi penyelesaiannya tidak langsung terlihat, sehingga dalam penyelesaiannya memerlukan pengetahuan, keterampilan dan pemahaman yang telah dipelajari sebelumnya. Sedangkan, Polya (dalam 
Hartono, 2014: 2) mengemukakan dua macam masalah matematika, yaitu:

1. Masalah untuk menemukan (problem to find) dimana kita mencoba untuk mengkontruksi semua jenis objek atau informasi yang dapat digunakan untuk menyelesaikan masalah tersebut.

2. Masalah untuk membuktikan (problem to prove) dimana kita akan menunjukkan salah satu kebenaran pernyataan, yakni pernyataan itu benar atau salah. Masalah jenis ini mengutamakan hipotesis ataupun konklusi dari suatu teorema yang kebenarannya harus dibuktikan.

Dari uraian tersebut, dapat disimpulkan bahwa yang dimaksud dengan masalah matematika adalah suatu masalah yang bisa dalam bentuk masalah untuk menemukan maupun membuktikan yang terdapat dalam pembelajaran matematika dimana dalam menyelesaikannya perlu pengetahuan, keterampilan, dan pemahaman dari orang yang mengerjakan masalah tersebut.

\section{Pemecahan Masalah Matematika}

Suatu masalah pasti mempunyai suatu penyelesaian, entah itu satu ataupun beberapa. Begitu pula dalam menyelesaikan masalah matematika. Walaupun terkadang sulit untuk memahami permasalahannya, setiap masalah matematika pastilah mempunyai pemecahan masalah. Pemecahan masalah adalah proses mengorganisasikan konsep dan keterampilan ke dalam pola aplikasi baru untuk mencapai suatu tujuan. Hal ini berbeda dengan penerapan pola yang biasa dikerjakan untuk mencapai tujuan yang pernah dilakukan. Mustofa (dalam Aufin, 2014: 102) mengatakan bahwa pembelajaran pemecahan masalah tidak sama dengan pembelajaran soal-soal yang telah diselesaikan (solved problems). Pada pemecahan masalah diberikan bekal kepada peserta didik berbagai teknik penyelesaian untuk menyelesaikan masalah. Strategi ataupun taktik untuk menyelesaikan masalah dengan cara ini disebut heuristik, karena pada dasarnya pembelajar harus dapat menemukan sendiri. Lencher (dalam Hartono, 2014: 3) mendefinisikan pemecahan masalah matematika sebagai "proses menerapkan pengetahuan matematika yang telah diperoleh sebelumnya ke dalam situasi baru yang belum dikenal."

Menurut Polya (dalam Hartono, 2014: 3) terdapat empat tahapan penting yang harus ditempuh siswa dalam memecahkan masalah, yakni memahami masalah, menyusun rencana penyelesaian, melaksanakan rencana penyelesaian, dan memeriksa kembali. Tahapan ini biasanya dikenal sebagai langkah Polya. Pada tahap memahami masalah, siswa harus dapat dengan jeli apa yang diketahui dan apa yang ditanyakan. Kemudian, pada tahap perencanaan siswa dapat merencanakan usaha apa yang akan ditempuhnya dalam usaha memecahkan masalahnya. Untuk tahap melaksanakan rencana, siswa melakukan apa yang telah direncanakan untuk menyelesaikan permasalahan tersebut. Dan tahap terakhir yaitu memeriksa kembali, siswa dapat mengecek kebenaran hasil yang didapat tanpa perlu menafsirkan hasilnya.

Menurut Branca (dalam Hartono, 2014: 3) pemecahan masalah dapat diintrepretasikan dalam tiga kategori yang berbeda. Pertama, pemecahan masalah sebagai tujuan. Kategori ini memfokuskan belajar bagaimana cara memecahkan masalah. Dalam hal ini, pemecahan masalah terbebas dari prosedur atau metode dan konten matematika itu sendiri. Kedua, pemecahan masalah sebagai proses. 
Kategori ini terfokus pada metode, prosedur, strategi, serta heuristik yang digunakan dalam pemecahan masalah. Ketiga, pemecahan masalah sebagai keterampilan dasar yang salah satunya menyangkut keterampilan minimal yang dimiliki siswa dalam menguasai matematika.

Dari uraian tersebut, dapat disimpulkan bahwa pemecahan masalah matematika adalah proses menerapkan pengetahuan matematika yang dimiliki seseorang untuk memecahkan suatu masalah dimana mempunyai empat tahapan penting atau biasa disebut sebagai langkah Polya yaitu, memahami masalah, menyusun rencana penyelesaian, melaksanakan rencana penyelesaian, dan memeriksa kembali.

\section{Strategi Pemecahan Masalah Matematika}

Strategi adalah cara berpikir dari seseorang dalam menyelesaikan suatu masalah. Sedangkan, strategi pemecahan masalah matematika adalah cara berpikir seseorang dalam menentukan suatu penyelesaian masalah matematika sesuai dengan kemampuan yang telah dipelajari. Matematika selalu dianggap sebagai pelajaran yang sulit karena soal- soalnya yang dianggap tidak mudah dikerjakan begitu saja tanpa berpikir keras. Tetapi, sebenarnya dalam mengerjakan soal- soal matematika terdapat strategi- strategi khusus sehingga soal- soal yang dihadapi dapat dikerjakan dengan mudah. Strategi yang digunakan ini tetapi harus strategi yang terbaik dan terefisien, sehingga harus memilih strategi mana yang paling tepat untuk digunakan.

Terdapat beberapa strategi pemecahan masalah matematika, tetapi strategi yang sering dikenal dan dipakai yaitu ada 10 (Hartono, 2014). Kesepuluh strategi ini haruslah bisa dipilih secara cermat, bahkan dari 10 strategi yang ada dapat dikombinasikan satu sama lainnya. Kesepuluh strategi pemecahan masalah matematika yang dimaksud adalah sebagai berikut:

1. Bekerja mundur

2. Menemukan pola

3. Melihat dari sudut pandang lain

4. Menyederhanakan masalah serupa

5. Mempertimbangkan kasus ekstrim

6. Membuat gambar atau diagram

7. Menebak dengan cerdas dan mengetesnya

8. Menghitung semua kemungkinan

9. Mengorganisasi data

10. Bernalar secara logis.

Dari strategi- strategi yang telah ada ini, diharapkan dalam menyelesaikan masalah matematika, siswa tidak lagi merasa kesulitan dalam mengerjakan soal- soal matematika.

\section{Strategi Pemecahan Masalah Matematika dengan Langkah Mundur dan Bernalar Secara Logis}

Kesepuluh strategi ini sangat berguna untuk menyelesaikan permasalahan- permasalahan matematika, selain itu masing- masing strategi juga mempunyai ciri khusus dalam penggunaanya. Dalam pembahasan kali ini, penulis fokus pada penggunaan strategi langkah mundur serta bernalar secara logis. Strategi langkah mundur ini merupakan cara yang berbeda dari strategi lain, dimana strategi ini memulai dari tujuan ataupun apa yang akan dibuktikan, ataupun apa yang telah diberikan pada soal. Dari poin ini, akan dicari sebuah pernyataan atau pernyataan yang berkaitan yang akan menyimpulkan tujuan dari soal. Sehingga, ciri dari strategi bekerja mundur adalah mengacu pada tujuan pada soal terlebih dahulu. Dari pernyataan ini, langkah mundur digunakan jika soal lebih mudah diselesaikan dari apa yang diminta. 
Selain langkah mundur, pada pembahasan kali ini strategi yang akan digunakan adalah bernalar secara logis. Bernalar, setiap orang memang pasti akan bernalar dalam menyelesaikan suatu permasalahan, tetapi proses bernalar yang dimaksud di sini adalah bernalar yang mana seseorang yang dihadapkan dengan permasalahan matematika mampu menemukan hal yang tersembunyi sehingga permasalahan tersebut dapat diselesaikan dengan mudah. Ciri dari strategi ini adalah akan ditemukannya pola dari soal yang diberikan. Pola yang telah ditemukan kemudian diaplikasikan pada permasalahan yang diberikan, sehingga permasalahan dapat diselesaikan tanpa perlu berpikir secara rumit dan panjang.

Selain kedua strategi tersebut, masih banyak strategi- strategi lain dengan cirinya masing- masing. Strategi- strategi yang ada juga dapat dikombinasikan antara satu dengan yang lain untuk saling melengkapi. Misalnya saja dalam pembahasan kali ini akan dikombinasikan antara strategi langkah mundur dengan bernalar secara logis. Keduanya dapat dikombinasikan dengan soal yang mana tujuan permasalahannya diketahui kemudian permasalahan tersebut mempunyai pola tertentu yang dapat memudahkan soal untuk bisa diselesaikan.

$\begin{array}{llr}\text { Sebagai } & \text { contoh misalnya } \\ \text { diberikan } & \text { permasalahan } & \text { untuk }\end{array}$
menentukan bilangan tiga digit, yaitu 2A3 jika ditambahkan dengan 326 akan menghasilkan bilangan tiga digit 5B9. Jika 5B9 habis dibagi 9, maka berapakah A? Karena fokus pada strategi langkah mundur dan bernalar secara logis, maka siswa haruslah memakai kombinasi dari strategi ini. Setelah itu, siswa dapat mengaplikasikan strategi langkah mundur ketika siswa mencari bilangan
B terlebih dahulu dimana 5B9 habis dibagi 9, setelah mendapat nilai $\mathrm{B}$ maka siswa dapat menentukan bilangan A. Untuk penerapan bernalar secara logis dapat diperlihatkan siswa dengan menjabarkan bahwa suatu bilangan yang terdiri dari tiga angka dari sini akan didapatkan suatu pola tertentu, artinya tiga bilangan tersebut mempunyai posisi sebagai ratusan, puluhan, serta satuan, sehingga posisi bilangan A yang ditanyakan adalah sebagai puluhan.

Sebagai contoh lain dari penggunaan kombinasi strategi ini adalah misalkan siswa diminta untuk mencari pecahan $\frac{N}{D}$ yang mana pecahan tersebut ekuivalen dengan desimal berulang 1,2666 $\overline{6}$ (Posamentier \& Krulik, 2008). Untuk menentukan pecahan $\frac{N}{D}$ ini dapat di cari dengan menggunakan kombinasi antara strategi langkah mundur dan bernalar secara logis. Strategi langkah mundur digunakan pada saat mulai mengerjakan soal dari bilangan yang telah diketahui, yaitu $1,2666 \overline{6}$, karena memang pada soal tidak terdapat petunjuk lain mengenai hal yang harus diselesaikan. Setelah itu, siswa haruslah mulai bernalar bagaimana agar angka $1,2666 \overline{6}$ bisa diubah menjadi suatu pecahan. Proses bernalarnya adalah siswa bisa 'membongkar' angka desimal tersebut menjadi penjumlahan yaitu $1,2+0,666 \overline{6}$. Kemudian, siswa dapat dengan mudah membentuk pecahan $\frac{N}{D}$ dan jika angkanya dapat disederhanakan maka buat pecahan sederhana agar angka yang didapat tidak terlalu besar. Dari sana, siswa dapat menjawab pertanyaan berapakah nilai pecahan $\frac{N}{D}$.

Penggunaan kombinasi strategi langkah mundur dan bernalar secara logis akan dibahas lebih lanjut pada 
aplikasi soal berikutnya. Dengan adanya kombinasi strategi- strategi ini kemungkinan penggunaan waktu akan menjadi lebih efektif dan soal yang dianggap sulit akan menjadi mudah dikerjakan.

\section{Teori Bilangan}

Materi- materi yang diajarkan dalam pembelajaran matematika sangat banyak jenisnya. Salah satunya adalah tentang teori bilangan. Teori bilangan adalah cabang dari matematika yang mempelajari sifat- sifat bilangan bulat dan mengandung berbagai masalah terbuka. Biasanya teori bilangan ini perlu strategi dan keterampilan yang cukup untuk bisa diselesaikan, sehingga jika seseorang itu menguasai strategistrategi tertentu, kemungkinan besar soal teori bilangan tersebut dapat diselesaikan.

Dalam teori bilangan juga terdapat beberapa materi yang dipelajari. Misalnya adalah menghitung faktor persekutuan terbesar, faktorisasi bilangan bulat, kekongruenan, dan masih banyak lagi. Dalam olimpiade matematika, baik tingkat SMP maupun SMA permasalahan teori bilangan lebih banyak disajikan dalam bentuk soal aplikasi. Dari soal- soal aplikasi ini, biasanya seseorang merasa tertantang ataupun merasa kesulitan untuk menjawabnya karena soal dalam bentuk aplikasi biasanya memang lebih sulit.

Menentukan suatu bilangan adalah salah satu contoh soal teori bilangan yang seringkali dikeluarkan dalam olimpiade. Soal untuk menentukan suatu bilangan biasanya sangat beragam, tergantung tingkat kesulitan soal. Misalnya saja dalam skala mudah, soal untuk menentukan suatu bilangan sudah ditentukan syaratsyaratnya di dalam soal dan penjawab soal hanya perlu meruntutkan apa yang telah diketahui pada soal. Tetapi, pada skala sulit, soal untuk menentukan suatu bilangan biasanya disatupadukan dengan materi- materi lain yang mana materi lain itu bisa menjadi strategi khusus yang bisa membuat soal tersebut mudah diselesaikan.

Selain menentukan suatu bilangan, contoh lain soal teori bilangan yang seringkali dikeluarkan dalam olimpiade adalah menentukan nilai dari suatu bilangan. Menentukan nilai dari suatu bilangan maksudnya adalah misal ditanyakan jumlah dari bilangan yang belum diketahui dengan bilangan lain yang juga belum diketahui. Tidak hanya jumlah tetapi operasi- operasi ataupun pertanyaan lainnya juga bisa menjadi masalah yang ditanyakan. Tingkat kesulitan menentukan nilai suatu bilangan ini lebih sulit dari menentukan suatu bilangan, karena dalam menentukan nilai suatu bilangan mau tidak mau penjawab soal harus mengetahui bilangan yang belum diketahui.

\section{Mencari Suatu Bilangan dengan Langkah Mundur dan Bernalar Logis}

Seperti yang telah diketahui sebelumnya, strategi dalam pemecahan matematika sangat beragam, bahkan bisa dikombinasikan antara satu dengan yang lainnya. Selain itu, salah satu cabang matematika yang sering dikeluarkan saat olimpiade adalah mengenai teori bilangan, dalam hal ini khususnya adalah untuk mencari suatu bilangan. Kemudian dalam menjawab permasalahan ini agar lebih terarah pemikiran dan langkah pengerjaannya, diharapkan menjawab dengan menggunakan langkah Polya. Penggunaan langkah Polya ditujukan agar penjawab soal mempunyai langkah pengerjaan yang terstruktur sehingga memudahkan dalam menjawab dan memahami permasalahannya. Seperti 
diketahui juga bahwa langkah Polya mempunyai empat tahapan, yaitu memahami masalah, menyusun rencana penyelesaian, melaksanakan rencana penyelesaian, dan memeriksa kembali. Berikut aplikasi penggunaan kedua strategi tersebut dalam menentukan suatu bilangan.

\section{Contoh 1 Olimpiade Sains Kabupaten Tingkat Kabupaten Tahun 2014 dari Kumpulan Soal OSK Matematika (Widodo, 2016)}

Diberikan tiga bilangan bulat positif berurutan. Jika bilangan pertama tetap, bilangan kedua ditambah 10 dan bilangan ketiga ditambah bilangan prima, maka ketiga bilangan ini membentuk deret ukur. Bilangan ketiga dari bilangan bulat berurutan adalah........

\section{Solusi dengan Menggunakan Langkah Mundur dan Bernalar Logis}

Berdasarkan langkah Polya diperoleh jawaban sebagai berikut:

\section{a. Memahami Masalah}

Pada soal tersebut dapat diuraikan sebagai berikut:

Diketahui bahwa terdapat tiga bilangan bulat yang berurutan. Bilangan tersebut akan membentuk deret ukur jika bilangan pertama tetap, bilangan kedua ditambah 10, dan bilangan ketiga ditambah bilangan prima. Ditanyakan berapakah bilangan ketiga dari bilangan bulat yang berurutan?

\section{b. Membuat Rencana untuk Menyelesaikan Masalah}

Setelah siswa memahami permasalahan tersebut, siswa bisa menyusun rencana penyelesaian dari permasalahan yang ada. Karena fokus pada strategi langkah mundur dan bernalar secara logis, maka siswa haruslah memakai kombinasi dari strategi ini. Tetapi, tidak menutup kemungkinan ada strategi lain selain kedua strategi ini yang dapat dimanfaatkan untuk menyelesaikan permasalahan tersebut. Pertama, langkah mundur digunakan dengan memulai dari memisalkan ketiga bilangan tersebut. Misal bilangan pertama adalah $a$, bilangan kedua adalah $b$, dan bilangan ketiga adalah $c$. Setelah itu, siswa dapat bernalar bahwa akan mencari ketiga bilangan tersebut dengan memikirkan bahwa nantinya ketiga bilangan itu akan berpola membentuk deret ukur jika $a$ tetap, $b$ ditambah 10, dan $c$ ditambah bilangan prima. Selain itu, siswa juga harus mencari tahu bilangan prima yang dimaksud agar deret ukur terpenuhi.

c. Melaksanakan Penyelesaian Soal Dalam soal tersebut, penyelesaiannya sesuai dengan strategi yang direncanakan adalah sebagai berikut:

Seperti diketahui dalam soal, ketiga bilangan tersebut akan membentuk deret ukur jika:

(i) Bilangan pertama $=a$

(ii) Bilangan kedua $=b+10$

(iii) Bilangan ketiga $=c+p$, $p$ adalah bilangan prima

Karena $a, b$, dan $c$ adalah bilangan yang berurutan, maka

$$
\begin{aligned}
& b=a+1 \\
& c=a+2
\end{aligned}
$$

Sehingga

(i) Bilangan pertama $=a$

(ii) Bilangan kedua $=a+1+10=$ $a+11$

(iii) Bilangan ketiga $=c+p=a+$ $2+p, p$ adalah bilangan prima

Karena ketiga bilangan ini membentuk barisan geometri, maka :

$$
U_{n}=U_{1} r^{n-1} \text { dan } r=\frac{U_{2}}{U_{1}}=\frac{a+11}{a}
$$

Jika diambil bilangan yang ketiga diperoleh

$$
\begin{gathered}
U_{3}=U_{1} r^{n-1} \\
\leftrightarrow a+2+p=a\left(\frac{a+11}{a}\right)^{3-1}
\end{gathered}
$$




$$
\begin{array}{cc} 
& \leftrightarrow a+2+p=a\left(\frac{a+11}{a}\right)^{2} \\
\leftrightarrow & a+2+p=\frac{(a+11)^{2}}{a} \\
\leftrightarrow & a+2+p=\frac{(a+11)^{2}}{a} \\
\leftrightarrow & (a)(a+2+p)=(a+11)^{2} \\
\leftrightarrow & a^{2}+2 a+a p \\
& =a^{2}+22 a+121 \\
\leftrightarrow & -20 a+a p=121 \\
\leftrightarrow & a(p-20)=121
\end{array}
$$

Selanjutnya, dipilih nilai $a$ merupakan faktor dari 121, sehingga dipilih $a=1, a=11$, dan $a=31$

- Jika $a=1$, maka $p-20=121$

$$
\leftrightarrow \quad p=141
$$

Karena $p=141 \quad$ bukan bilangan prima, maka bukan merupakan penyelesaian yang diinginkan.

- Jika $a=11$, maka $p-20=11$

$$
\leftrightarrow \quad p=31
$$

Karena $p=31$ bilangan prima, maka hal ini merupakan penyelesaian yang diinginkan.

- Jika $a=121$, maka $p-20=1$

$$
\leftrightarrow \quad p=21
$$

Karena $p=21$ bukan bilangan prima, maka bukan merupakan penyelesaian yang diinginkan.

$\therefore p=31$ dan $a=11 \quad$ sehingga bilangan ketiganya adalah $c=a+2=$ $11+2=13$

\section{d. Memeriksa Ulang Jawaban yang Diperoleh}

Pada soal tersebut, jika ditinjau ulang bahwa jika $a=11$, maka $b=11+$ $1=12$, dan $\quad c=11+2=13$. Sehingga benar bahwa ketiga bilangan tersebut berurutan.

Kemudian untuk syarat yang kedua, jika $a=11, \mathrm{~b}=12+10=22$, dan $\mathrm{c}=$ $13+31=44, \mathrm{p}=31$ maka akan membentuk deret ukur dengan rasio 2 . Jadi, benar bahwa bilangan ketiga dari urutan bilangan tersebut adalah 13 .

Dengan demikian, dengan menggunakan strategi langkah mundur dan bernalar secara logis, permasalahan teori bilangan mengenai menentukan suatu bilangan akan sangat mudah diselesaikan jika siswa menguasai strategi tersebut. Strategi ini juga tidak membutuhkan waktu yang relatif lama, jika dibandingkan dengan siswa mencoba satu persatu bilangan mana yang cocok dengan pernyataan pada soal.

Contoh 2 (Olimpiade Sains Kabupaten Tingkat Kabupaten Tahun 2005 dari Kumpulan Soal Olimpiade Matematika (Hermanto, 2015)

Tentukan semua bilangan tiga-angka sehingga nilai bilangan itu adalah 30 kali jumlah ketiga angka itu. (OSK SMA TAHUN 2005)

\section{Solusi dengan Menggunakan Langkah Mundur dan Bernalar Logis}

Berdasarkan langkah Polya diperoleh jawaban sebagai berikut:

\section{a. Memahami Masalah}

Pada soal tersebut dapat diuraikan sebagai berikut:

Diketahui bahwa terdapat bilangan tiga angka. Kemudian nilai ketiga angka itu 30 kali dari jumlah ketiga angka itu. Kemudian ditanyakan berapakah angka yang dimaksud?

\section{b. Membuat Rencana untuk Menyelesaikan Masalah}

Dari permasalahan tersebut dapat dibuat rencana penyelesaiannya dengan memilih langkah mundur dan berpikir secara logis, yaitu sebagai berikut:

Akan dibagi secara terpisah dari bilangan tiga angka yang dimaksud, karena terdiri dari tiga buah angka, maka angka tersebut terdiri dari angka ratusan, puluhan, dan satuan.

Kemudian untuk angka tersebut nilainya adalah 30 kali dari jumlah ketiganya. Misalkan angka tersebut adalah $n, n=100 a+10 b+c$. 


\section{c. Melaksanakan Penyelesaian Soal}

Dalam soal tersebut, penyelesaiannya sesuai dengan strategi yang direncanakan adalah sebagai berikut:

Seperti diketahui dalam soal dan memisalkan angka tersebut, maka jika dibagi menjadi angka ratusan, puluhan, dan satuan menjadi:

$n=100 a+10 b+c \quad$ karena nilai bilangan tersebut adalah 30 kali jumlah bilangannya, maka

$$
n=30(a+b+c) \text {, }
$$

a adalah angka ratusan, $b$ adalah angka

puluhan,

dan $c$ adalah angka satuan

$\leftrightarrow 100 a+10 b+c=30(a+b+c)$

$\leftrightarrow 100 a+10 b+c=30 a+30 b+$ $30 c$

$$
\begin{array}{ll}
\leftrightarrow & 70 a-20 b=29 c \\
\leftrightarrow & 10(7 a-2 b)=29 c \\
\leftrightarrow & \frac{c}{(7 a-2 b)}=\frac{10}{29}
\end{array}
$$

Karena 10 dan 29 relatif prima, maka $7 a-2 b=29 k$ dan $c=10 k$.

Karena $0 \leq c \leq 9$, maka nilai k yang memenuhi hanya $\mathrm{k}=0$ sehingga $\mathrm{c}=0$.

Sehingga $7 a=2 b \leftrightarrow \frac{a}{b}=\frac{2}{7}$, karena 2 dan 7 relatif prima sedangkan

$0 \leq a$ dan $b \leq 9$, maka nilai $a$ dan $b$ yang memenuhi adalah $a=2$ dan $b=$ 7.

$\therefore$ Bilangan 3 angka yang dimaksud adalah 270 .

\section{d. Memeriksa Ulang Jawaban yang Diperoleh}

Pada soal tersebut, pertama karena bilangan yang didapatkan adalah 270, maka jika dipisah sesuai dengan ratusan, puluhan, dan satuan menjadi $n=100(2)+10(7)+0$ dengan nilai $a=2, b=7$, dan $c=0$

Sehingga, jumlah dari ketiga bilangan tersebut adalah

$a+b+c=2+7+0=9$

Jadi, $\quad n=30(a+b+c) \leftrightarrow 270=$ $30 \times 9(B E N A R)$

Sehingga benar bilangan yang dimaksud adalah 270 .

\section{Mencari Nilai Bilangan dengan Langkah Mundur dan Bernalar Logis}

Tak lain halnya dengan menentukan suatu bilangan, menentukan nilai dari suatu bilangan adalah contoh pengembangan permasalahan lain dari teori bilangan. Menentukan nilai suatu bilangan sebenarnya adalah menentukan nilai dari operasi- operasi bilangan yang belum diketahui pada soal. Permasalahan ini diawali dengan siswa harus mengetahui berapa bilangan yang nantinya akan dioperasikan. Setelah siswa mengetahui bilangan tersebut, siswa barulah dapat melakukan operasi matematika.

Menentukan nilai suatu bilangan juga lebih mudah jika diselesaikan dengan strategi pemecahan permasalahan matematika, khususnya dengan langkah mundur dan bernalar secara logis. Hal ini dikarenakan dalam menentukan nilai suatu bilangan, siswa mencari bilangan yang dimaksud terlebih dahulu. Sebelumnya, telah dibahas bahwa dalam menentukan suatu bilangan lebih mudah dilakukan dengan strategi langkah mundur dan bernalar secara logis dibandingkan dengan 
mencoba satu persatu bilangan yang dicari. Sehingga penerapan strategi langkah mundur dari menentukan nilai suatu bilangan adalah saat mencari bilangan yang belum diketahui sebelumnya, sedangkan strategi bernalar secara logis dapat diterapkan saat mencari nilai bilangan tersebut, misal jika dalam menentukan nilai bisa diperoleh dari suatu persamaan maka siswa tidak perlu mendaftar semua bilangan yang tidak diketahui.

Langkah pengerjaan yang dilakukan dalam mencari nilai bilangan ini juga menggunakan langkah Polya. Sama dengan menentukan suatu bilangan, dalam menentukan nilai bilangan langkah Polya terdiri dari empat tahapan yaitu memahami masalah, menyusun rencana penyelesaian, melaksanakan rencana penyelesaian, dan memeriksa kembali.

\section{Contoh 3 Olimpiade Sains Kabupaten Tingkat Kabupaten Tahun 2016 dari Kumpulan Soal OSK Matematika (Widodo, 2016)}

Jika $a, b, c, d, e$ merupakan bilangan asli dengan $\quad a<2 b, b<3 c, c<4 d, d<$ $5 e$, dan $e<100$, maka nilai maksimum dari $a$ adalah...............(OSK SMA tingkat Kabupaten 2016)

\section{Solusi dengan Menggunakan Langkah Mundur dan Bernalar Logis}

Berdasarkan langkah Polya diperoleh jawaban sebagai berikut:

\section{a. Memahami Masalah}

Pada soal tersebut dapat diuraikan sebagai berikut:

Diketahui bahwa terdapat lima buah bilangan, yaitu $a, b, c, d$,dan $e$. Dari lima bilangan tersebut ditentukan bahwa

$$
\begin{aligned}
& \text { (i) } a<2 b \\
& \text { (ii) } b<3 c
\end{aligned}
$$

$$
\begin{aligned}
& \text { (iii) } c<4 d \\
& \text { (iv) } d<5 e \\
& \text { (v) } e<100
\end{aligned}
$$

Kemudian ditanyakan berapakah nilai maksimum dari $a$.

\section{b. Membuat Rencana untuk Menyelesaikan Masalah \\ Sama seperti dalam menentukan} suatu bilangan, siswa harus dapat memahami permasalahan tersebut barulah siswa bisa menyusun rencana penyelesaian dari permasalahan yang ada. Karena fokus juga pada strategi langkah mundur dan bernalar secara logis, maka siswa haruslah memakai kombinasi dari strategi ini. Tetapi, tidak menutup kemungkinan ada strategi lain selain kedua strategi ini yang dapat dimanfaatkan untuk menyelesaikan permasalahan tersebut.

Dari permasalahan tersebut dapat dibuat rencana penyelesaiannya dengan memilih langkah mundur dan berpikir secara logis, yaitu sebagai berikut:

Pertama, langkah mundur digunakan dengan memulai mengurutkan bilangan dari yang telah diketahui terlebih dahulu yaitu pernyataan kelima dimana $e<100$. Sedangkan, bernalar secara logis dipakai dengan memikirkan pola jika diketahui interval- interval angka seperti pada soal, maka setiap bilangan tersebut diapit oleh bilangan lain atau dalam artian lain mempunyai batas bawah maupun batas atas. Sehingga siswa harus memanfaatkan pola interval- interval dari setiap bilangan yang belum diketahui.

\section{c. Melaksanakan Penyelesaian Soal}

Dalam soal tersebut, penyelesaiannya sesuai dengan strategi yang direncanakan adalah sebagai berikut:

Seperti diketahui dalam soal

$$
\begin{aligned}
& e<100, \quad \text { artinya } \quad e \leq 99 \\
& \text { sehingga } d<5 \times e \leftrightarrow d<5 \times \\
& 99
\end{aligned}
$$

$$
\leftrightarrow d<495
$$




$$
\begin{aligned}
& d<495, \quad \text { artinya } \quad d \leq 494 \\
& \text { sehingga } c<4 \times d \leftrightarrow c<4 \times \\
& 494 \\
& \leftrightarrow c<1976 \\
& c<1976 \text {, artinya } c \leq 1975 \\
& \text { sehingga } \\
& b<3 \times c \leftrightarrow b<3 \times 1976 \\
& \leftrightarrow b<5925 \\
& b<5925 \text {, artinya } b \leq 5924 \\
& \text { sehingga } \\
& a<2 \times b \leftrightarrow a<2 \times 5924 \\
& \leftrightarrow a<11848 \\
& a<11848 \text {, artinya } a \leq 11847
\end{aligned}
$$

Karena $a \leq 11847$ maka batas bawah dari $a$ adalah 11847. Dari batas bawah ini dapat dijadikan sebagai nilai maksimal dari $a$, sehingga diperoleh nilai maksimal dari $a$ adala 11847 .

\section{d. Memeriksa Ulang Jawaban yang Diperoleh}

Pada soal tersebut, jika diambil bahwa nilai $a$ adalah 11847 maka $a \leq 11847$, dalam arti lain $a<11848$. Setelah itu beranjak ke persyaratan pertama, yaitu $a<2 b$, anggap 11848 adalah batas atas dari $2 b$ sehingga $11848 \leq 2 b$ kemudian untuk mencari batasan dari $b$ adalah dengan membagi 11848 dengan 2 dan diperoleh $\frac{11848}{2} \leq b \leftrightarrow 5924 \leq$ $b$. Jadi, batas atas dari $b$ adalah 5924 dan diperoleh $5925<b$. Setelah itu beranjak ke persyaratan kedua, yaitu $b<3 c$, anggap 5925 adalah batas atas dari $3 c$ sehingga $5925 \leq 3 c$ kemudian untuk mencari batasan dari $c$ adalah dengan membagi 5925 dengan 3 dan diperoleh $\frac{5925}{3} \leq c \leftrightarrow 1975 \leq c$. Jadi, batas atas dari $c$ adalah 1975 dan diperoleh $1976<c$. Setelah itu beranjak ke persyaratan ketiga, yaitu $c<4 d$, anggap 1976 adalah batas atas dari $4 d$ sehingga $1976 \leq 4 d$ kemudian untuk mencari batasan dari $d$ adalah dengan membagi 1976 dengan 4 dan diperoleh $\frac{1976}{4} \leq d \leftrightarrow 494 \leq d$. Jadi, batas atas dari $d$ adalah 494 dan diperoleh $495<d$. Setelah itu beranjak ke persyaratan keempat, yaitu $d<5 e$, anggap 495 adalah batas atas dari $5 e$ sehingga $495 \leq 5 e$ kemudian untuk mencari batasan dari $e$ adalah dengan membagi 495 dengan 5 dan diperoleh $\frac{495}{5} \leq 99 \leftrightarrow 99 \leq e$. Jadi, batas atas dari $e$ adalah 99 dan diperoleh $100<$ $e$. Hal ini sesuai dengan soal yang diketahui.

Dengan demikian, penggunaan strategi langkah mundur dan bernalar secara logis permasalahan teori bilangan mengenai menentukan nilai suatu bilangan akan memudahkan siswa dalam menyelesaikan soal jika sudah menguasai strategi tersebut. Berbagai permasalahan lain mengenai menentukan nilai suatu bilangan akan ditampilkan pada pembahasan diambil dari soal- soal olimpiade tingkat SMA.

\section{Contoh 4 Olimpiade Sains Kabupaten Tingkat Kabupaten Tahun 2016 dari Kumpulan Soal OSK Matematika (Widodo, 2016)}

Misalkan $a$ adalah bilangan real sehingga polynomial $p(x)=x^{4}+4 x+$ $a$ habis dibagi oleh $(x-c)^{2}$ untuk suatu bilangan real $c$. Nilai $a$ yang memenuhi.

\section{Solusi dengan Menggunakan Langkah Mundur dan Bernalar Logis}

Berdasarkan langkah Polya diperoleh jawaban sebagai berikut:

\section{a. Memahami Masalah}

Pada soal tersebut dapat diuraikan sebagai berikut:

Diketahui bahwa terdapat bilangan real $a$, dan juga terdapat polinomial $p(x)=x^{4}+4 x+a$ yang habis dibagi dengan $(x-c)^{2}, c \in \mathbb{R}$. Kemudian ditanyakan berapakah nilai dari $a$ ? 


\section{b. Membuat Rencana untuk Menyelesaikan Masalah}

Dari permasalahan tersebut dapat dibuat rencana penyelesaiannya dengan memilih langkah mundur dan berpikir secara logis, yaitu sebagai berikut:

Akan diselesaikan dengan memulai bahwa polinomial yang diketahui yaitu $p(x)=x^{4}+4 x+a$ habis dibagi dengan $(x-c)^{2}$, artinya $(x-c)^{2}$ adalah salah satu faktor dari polynomial tersebut dan $c \neq 0$. Dengan menguraikan pemfaktoran dari polinomial tersebut, maka akan didapat nilai $a$.

\section{c. Melaksanakan Penyelesaian Soal}

Dalam soal tersebut, penyelesaiannya sesuai dengan strategi yang direncanakan adalah sebagai berikut:

Seperti diketahui dalam soal polinomial tersebut dapat diuraikan menjadi

$p(x)=(x-c)^{2}\left(x^{2}+b x+\frac{a}{c^{2}}\right)$, hal ini karena $(x-c)^{2}$ adalah faktor dari polinomial tersebut dan polinomial tersebut adalah pangkat 4 .

$\leftrightarrow x^{4}+4 x+a=(x-c)^{2}\left(x^{2}+b x+\right.$ $\left.\frac{a}{c^{2}}\right)$

$\leftrightarrow x^{4}+4 x+a=\left(x^{2}-2 c x+\right.$

$\left.c^{2}\right)\left(x^{2}+b x+\frac{a}{c^{2}}\right)$

$\leftrightarrow x^{4}+4 x+a=x^{4}+b x^{3}+\frac{a}{c^{2}} x^{2}-$

$2 c x^{3}-2 b c x^{2}-2 \frac{a}{c} x+c^{2} x^{2}+$

$b c^{2} x+a$

$\leftrightarrow x^{4}+4 x+a=x^{4}+(b-2 c) x^{3}+$ $\left(\frac{a}{c^{2}}-2 b c+c^{2}\right) x^{2}+\left(-2 \frac{a}{c}+b c^{2}\right) x+$ $a$

Dengan menyamakan ruas kiri dan ruas kanan diperoleh

$$
\begin{array}{ll}
\text { i. } & b-2 c=0 \\
\text { ii. } & \frac{a}{c^{2}}-2 b c+c^{2}=0 \\
& \frac{a}{c^{2}}-4 c^{2}+c^{2}=0, \text { karena dari } \\
& b=2 c \\
\text { i) } \quad & \frac{a}{c^{2}}-3 c^{2}=0 \\
& a-3 c^{4}=0
\end{array}
$$

$$
\begin{aligned}
& a=3 c^{4} \\
& \text { iii. } \quad-2 \frac{a}{c}+b c^{2}=4 \\
&-\frac{2 \times 3 c^{4}}{c}+2 c^{3}=4, \text { karena dari } \\
& \text { (i) } b=2 c \text { dan (ii) } a=3 c^{4} \\
&-6 c^{3}+2 c^{3}=4 \\
&-4 c^{3}=4 \\
& c^{3}=-1 \\
& c=-1
\end{aligned}
$$

Dari (ii) $a=3 c^{4}$, karena $c=-1$ maka $a=3 c^{4} \leftrightarrow a=3 \times(-1)^{4} \leftrightarrow$ $a=3$

Jadi, nilai $a=3$.

\section{d. Memeriksa Ulang Jawaban yang Diperoleh}

Pada soal tersebut, jika ditinjau ulang bahwa jika diperoleh nilai $a=3, b=$ -2 , dan $c=-1$, maka bentuk polynomial yang didapatkan menjadi

$$
p(x)=x^{4}+4 x+3
$$

Jika difaktorkan $p(x)=(x-c)^{2}\left(x^{2}+\right.$ $\left.b x+\frac{a}{c^{2}}\right)$ menjadi

$$
\begin{aligned}
p(x)= & (x+1)^{2}\left(x^{2}-2 x+\frac{3}{1}\right) \\
p(x)= & \left(x^{2}+2 x+1\right)\left(x^{2}-2 x+3\right) \\
p(x)= & x^{4}-2 x+3 x^{2}+2 x^{3}-4 x^{2}+ \\
& 6 x+x^{2}-2 x+3 \\
p(x)= & x^{4}+4 x+3
\end{aligned}
$$

Hal ini sesuai dengan polinomial yang diketahui, maka benar jika nilai $a=3$.

\section{KESIMPULAN DAN SARAN}

Dari kajian ini, terdapat beberapa hal yang dapat disimpulkan :

1. Dari hasil analisis contoh soal olimpiade yang telah dikerjakan, soal tersebut telah mengarah kepada aplikasi soal dari teori bilangan. Kedua contoh soal tersebut dapat dengan mudah jika dikerjakan dengan menggunakan strategi langkah mundur dan bernalar secara logis. Penerapan langkah mundur dilakukan dengan mengerjakan soal tersebut dimulai dari pernyataan yang diketahui. 
Pada soal, pernyataan yang diketahui adalah pernyataan dari belakang, sehingga memungkinkan soal tersebut dikerjakan dengan langkah mundur. Kemudian penerapan bernalar secara logis diterapkan ketika siswa mulai mencari pola- pola dari soal yang diketahui. Setelah mengetahui polanya dan dikerjakan secara mundur, maka siswa dapat menyelesaikan soal tersebut.

2. Dari kedua contoh soal, kedua soal baik dalam menentukan bilangan ataupun nilai suatu bilangan sangat efektif jika dikerjakan dengan mengombinasikan kedua strategi yaitu langkah mundur dan bernalar secara logis. Karena apabila siswa mengerjakan secara manual yaitu dengan cara mencoba- coba, maka waktu yang dihabiskan terlalu banyak. Padahal biasanya dalam mengerjakan soal- soal olimpiade hanya diberikan waktu yang singkat, sehingga strategi- strategi yang dipilih siswa haruslah tepat dan cepat.

Saran dari penulis adalah dengan adanya strategi- strategi yang telah dikenal, siswa hendaknya bisa memanfaatkan strategi- strategi tersebut sehingga penggunaan waktu dan kemungkinan benar menjawab soal semakin tinggi. Selain itu, dari kesepuluh strategi yang ada pada pembahasan kali ini, juga bisa dikombinasikan antara satu dengan yang lainnya, tidak hanya strategi langkah mundur dan bernalar secara logis saja. Selain itu, kemungkinan masalah yang bisa menggunakan kombinasi strategi langkah mundur dan bernalar secara logis tidak hanya dalam menentukan suatu bilangan dan menentukan nilai dari suatu bilangan sehingga penulis menyarankan agar penulis lain untuk membahas permasalahan apa yang dapat menggunakan kombinasi strategi langkah mundur dan bernalar secara logis ataupun kombinasi strategi lain yang dapat memecahkan permasalahan matematika.

\section{DAFTAR PUSTAKA}

Aufin, M. 2012. Komunikasi dan Pemecahan Masalah dalam Pembelajaran Matematika. http://jurnal.yudharta.ac.id/wpcontent/uploads/2014/09/Komun ikasi-dan-Pemecahan-Masalahdalam-PembelajaranMatematika.pdf. diakses 6 April 2017.

Budhi, W.S., dan Kartasasmita, B.G. 2015. Berpikir Matematis Matematika Untuk Semua. Jakarta: Erlangga.

Hartono, Y. 2014. Matematika; Strategi Pemecahan Masalah. Yogyakarta: Graha Ilmu.

Hermanto, E. 2015. Kumpulan Soal Olimpiade Matematika Tahun 2002-2009.

http://www.edukasicampus.net/2 015/11/soal-dan-pembahasanolimpiade.html. diakses 6 April 2017.

Posamentier, A. S., \& Krulik, S. 2008. Problem-solving strategies for efficient and elegant solutions grades 6-12. Thousand Oakes, CA: Corwin Press.

Widodo, Tutur. 2016. Kumpulan Soal OSK Tahun 2011- 2016. http://tuturwidodo.com/downloa d/. diakses 6 April 2017. 